\title{
Scientific publishing as the arena of power and caring
}

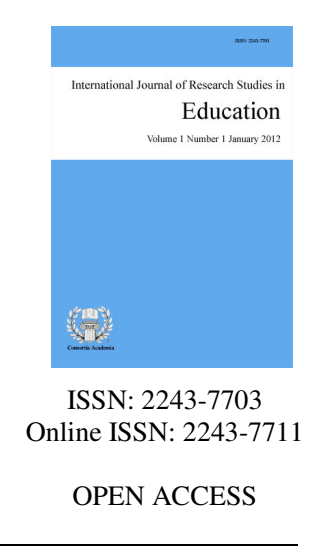

Uusiautti, Satu $\$

Faculty of Education, University of Lapland, Finland (satu_uusiautti@hotmail.com)

\section{Abstract}

Scientific publishing has become one of the most important means of not only advancing researchers' careers but also securing funding for universities. Therefore, the atmosphere in academic communities often appears very competitive, which can harm trust and open collaboration between colleagues. What is the role of co-authorship in writing? How to perceive the peer review process as a part of publishing and scientific discourse? In this article, scientific publishing of research studies in peer reviewed journals is viewed as an arena of power and caring. This viewpoint has basically two purposes: (1) to discuss the possibility of caring review process and (2) to discuss the possibility of caring collaboration between researchers in scientific writing. The power of collaboration and benefits of caring reviews are introduced as conclusions.

Keywords: scientific publishing; caring research; co-author; peer review; caring collaboration 


\section{Scientific publishing as the arena of power and caring}

\section{Introduction}

Research and the researcher do not become acknowledged without writing and publishing about the research results and findings. Every researcher dreams of writing research articles so that they convince, further scientific discussion, are to credit, and show the researcher's talents and quality of his or her research work. Plenty of high-quality publications is the goal of many researchers.

This article is about the process of publishing an article. The purpose here is to use this part of academic life as an example of viewing the possibility of positive, caring practices in science. On the one hand, articles go through peer reviews which are an important arena of scientific discussion. The first attempt in this paper is to view peer-reviewing as a caring form of researcher interaction. This viewpoint is largely based on my former work as a specialist of scientific publishing in my institution, peer-review data obtained during this period as well as on numerous memberships in editorial boards and peer reviewer nominations in various journals. On the other hand, this paper wants to discuss the publishing process especially from a researcher's perspective. How to cope with the increasing demands on publishing? One way is to indulge in collaboration with colleagues. This is not, however, as simple as that in universities. However, a supportive, open-minded collaboration could be a way of increasing not only the number of publications but also the quality of them. The author's numerous studies in the field of well-being and success at work especially from the positive educational psychological viewpoint have worked as the foundation of this perspective (see e.g., Uusiautti, 2008; 2013; Uusiautti \& Määttä, 2015). This article will combine these viewpoints and attempts to have a look at the dilemmas of (1) whether a caring review process is possible and, if it is, how to define it, and (2) whether caring collaboration in academic teams is possible and, if it is, how to define it.

\subsection{The pressure of publishing}

The implications of the manuscript review and decision-making process for both scientific knowledge and scientists' careers are widely acknowledged (Bakanic, McPhail, \& Simon, 1987). Publishing is important not only to researchers themselves but to universities: funding is greatly based on the researchers' abilities to publish high-quality scientific articles. Wen, Ching, and Tang (2013) have described knowledge production as a market-like operation characterized by internationalization and competition. It means that published journal articles are valuable in a very concrete manner. They also serve as merits when applying for research funding or starting research projects (Marsh, Jayasinghe, \& Bond, 2008). The term "publish or perish" has become more than familiar to researchers across the world (e.g., Ching, 2013; Roth 2002). Likewise, reading and citing readings in grant proposals or reports are considered essential (Tenopir, Mays, \& Wu, 2011).

Publishing is an important part of academic life. It is also the arena where researchers become known. Naturally, publishing happens in many forms: in addition to scientific, peer-reviewed articles in national and international journals or edited books, publishing covers conference and seminar presentations and other reports and publications introducing research results. There is no research without publishing. Every new publication arouses new studies and thus promotes science by expanding and deepening knowledge. The purpose of scientific discourse is to evaluate the relationship between new and earlier research results and theories and cherish and advance the quality of research. In this article, I will focus on journal article publishing.

\subsection{Peer review as the important part of scientific publishing}

One important form of scientific discussion - a very direct one-is the peer review process of manuscript aimed to be published. The most respectable journals lean on these peer review processes when making 
decisions on publishing manuscripts. Peer review means anonymous feedback given to the author of an article considering the quality of the manuscript and the study introduced in it.

Peer-review practice is acknowledged as the fundamental quality-control method-in other words, a gate keeper-in academic journals (Bornman \& Daniel, 2009; Eisenhart, 2002; Larochelle \& Désautels, 2002). Actually, the history of the review process has developed from informal discussions between scholars by letters into anonymous assessing and judgment of others' work (Larochelle \& Désautels, 2002). Therefore, peer review has long been a tradition of scholarly journal publication (Bakanic, McPhail, \& Simon, 1987). Peer review practices have been studied from various aspects as well; for example, the affect that the choice of referees may have on editors' decisions (Bornman \& Daniel, 2009), the randomness of prescreening before review (Neff \& Olden, 2006), wrongly rejected, highly-cited, innovative articles (Campanario, 1996), authors' editorial experiences (Bedeian, 2003), authors' replies to referees' comments in peer reviews (Gosden, 2001), and peer reviews in scholarly electronic journals (Harnad, 1996).

Hardly anyone is able to write a perfect article at once, not even if the study reported was very spectacular. Therefore, the peer review process is important. Also, journals have their specific requirements for articles regarding their formatting, structure, and contents of each chapter. Authors have to follow these carefully. In addition, the submitting instructions can vary considerably, and journals tend to have their own online systems. Using them requires specific ICT skills. Only after having successfully submitted one's manuscript to a journal, the paper can go to review. First, the manuscript has to pass an initial check regarding its fit with the scope and purpose of the journal. Then, the editors start to recruiting reviewers for the paper. The researcher has to accept the review process as a means to learn to be even better author. Next, we will have a closer at that.

\section{At the mercy of peer reviewers!}

Publishing in academic journals is an extremely interesting procedure. Those who publish actively are familiar with the wide spectrum of reviews; you can never know what kind of comments you will have after a week or even month-long review process. The researcher just has to wait patiently the feedback and comments, and the editor-in-chief's decision.

The styles of evaluation in peer-reviews have also been studied (e.g., Fortanet, 2008; Gosden, 2003). Bakanic, McPhail, and Simon (1987) describe the differences in journal's practices as follows: "[a]ll manuscripts may not be processed or assigned to reviewers in the same way. This varies within as well as across disciplines and journals. Manuscripts are handled differently when they are resubmitted after an initial rejection than when revised and resubmitted at the editor's request or when conditionally accepted. Not every submitted manuscript is assigned for peer review" (p. 632).

There are also studies of what makes a good reviewer. A decorous reviewer can protect authors from making errors and improve the quality of their manuscript, while some reviewers would apparently like to re-write the article by themselves (Bedeian, 1996). Black et al.'s (1998) study showed the interesting association between the review quality and certain reviewer characteristics-or lack thereof. Instead of those reviewers who were actively involved in research, occupied academic positions and were members of research funding bodies, reviewers with appropriate education in the field of the article under review and time spent with the review task appeared more important when assessing the quality of a review. Furthermore, writing good reviews is a skill that develops only with practice (Benos, Kirk, \& Hall, 2003).

There are certain ethical rules that Benos et al. (2003) call "the etiquette of review" and that the reviewers are expected to follow. In sum, the rules are the following: (1) The reviewer should provide an honest, critical assessment of the research; (2) The reviewer should maintain confidentiality about the existence and substance of the manuscript; (3) The reviewer must not participate in plagiarism; (4) The reviewer should always avoid, or disclose, any conflicts of interest; (5) The reviewer should accept manuscripts for review only in his/her areas of expertise; (6) The reviewer should agree to review only those manuscripts that can be completed on time; (7) 
The reviewer also has the unpleasant responsibility of reporting suspected duplicate publication, fraud, plagiarism or other ethical concerns; and (8) The reviewer should write reviews in a collegial, constructive manner (adopted from Benos et al., 2003, pp. 49-50; see also Uusiautti, 2015).

Usually, a manuscript will be reviewed by two or more experts from the same scientific field. They are doctors, professors, researchers, and specialists across the world. Abundant publishing also often means abundant requests for acting as a reviewer: researchers who have plenty of publications become noticed and acknowledged as experts capable of reviewing others' papers.

Peer-reviewers are asked to contribute a written evaluation about an article. They have to give a recommendation whether to accept or reject the paper, and the editor-in-chief makes the decision based on this recommendation and evaluation. I studied peer-review evaluations when working as a specialist of scientific publication, and my notes are based on over 100 published articles during that period. I also have plenty of practical knowledge about the process due to my role as a member of editorial boards and as a reviewer for about 20 journals. I conducted a qualitative study on the review process. The reviews were mainly from the fields of educational psychology and the science of education. According to my data that included 123 separate review reports, the evaluations could be roughly described after the content analysis procedures of the report data (see further information in Uusiautti, 2015) as follows:

$>$ Favoring reviews: The result of the review is "accept as-is". The peer referee applauds the manuscript and does not present any criticism or unconditional revisions to the article. However, the commentary can be very detailed but praising.

$>$ Constructive reviews: The result of the review is "accept with (minor/major) revisions /resubmit". The peer referee provides constructive comments that are very detailed. The language the referee uses is friendly and objective. The suggested revisions are presented in context.

$>\quad$ Critical reviews: The result of the review is "accept with major revisions/resubmit". The peer referee's comments can be very detailed but not always constructive. The common feature of these reviews is criticism and doubt. The language the referee uses is aggressive, even discourteous. What separates the category from constructive reviews is the manner of expression. Although both might be considered honest, critical reviews can have a mocking tone; e.g. "It is a hodge-podge [...]"

$>\quad$ Superficial reviews: These reviews are extremely brief, only a few lines. The peer reviewer points out only superficial issues and therefore the comments are not very constructive or detailed. Superficial reviews can be favoring or critical.

$>$ Rejecting reviews: The result of the review is "rejected". The peer reviewer highlights the most crucial concerns that justify the rejection or that the reviewer considers in need of revision before even thinking of submitting the article elsewhere.

Despite the established guidelines for reviews, the contents of evaluations seem to vary considerably (e.g., Blank, 1991; Eisenhart, 2002; Grimm, 2005; Lock, 1982). The superficial reviews category showed this clearly. It was also interesting to compare the review results of well-written, appraised articles with the results of issues needing revision (Uusiautti, 2015): For example, methodological concerns were highlighted the most but when they were well-written, methodological issues were not specifically appraised in favoring reviews. Instead, well-written theoretical and literature reviews were often highlighted by referees when they recommended an article to be accepted as-is. On the other hand, theory and literature reviews were not among the most popular issues in revision suggestions.

The truth is that it is very rare that a manuscript is accepted as is. There is always something to improve, and constructive comments will help revise the problematic sections of the manuscript. Everyone writing actively knows how they become blind to their own texts! One also has to be prepared to receive downright criticism, 
because the reviewers' words are not always flattering, quite the opposite. There is no reason to be offended, and at least not to lose heart for them, but to read them like a professional: what should be revised and improved in the text, how to address the criticism in general. Indeed, Glenn (1976) sighed four decades ago "who knows how many persons have failed to receive tenure, promotions, and pay raises because of patently unfair rejections of their papers" (p. 181). He implies that not always have the reviewers given full consideration to their words. However, the methodological solutions, their justifications, and descriptions of data collection and analyzing procedures as well as familiarity with earlier research in the field as presented in the manuscript are under specific inspection in reviews. The manuscript should end with clearly showing the contribution of the study, this is called the so-what-factor. Therefore, it is always crucial to be open to criticism whenever showing lack of solid argumentation in your text. One review stated in my data as follows:

"Overall, my feeling is that the paper appears to take for granted a number of things which need to be more robustly defended. - - The authors appear to assume that the reader will already agree with them on many questions that are at least controversial."

\section{Caring reviews-just impossible?}

Based on these findings, the variation in reviews and the review processes in the journals imply that work has to be done to (a) guarantee the quality of a review, (b) make the review easier to write for the referee and easier to understand for the author, and (c) make the review process faster. For example, according to Lotriet (2012), in medical field, approximately $70 \%$ of reviewers fail to submit their reviews in time. The increase in online publishing demands, however, efficiency from reviewers as well (Tenopir, Mays, \& Wu, 2011). Therefore, the review process is under constant development and evaluation. Even though the core issues on which reviewers should focus when doing reviews are quite conventional, the new forms of publication, faster publishing procedures, and increasing interest in transparent review processes demand critical analysis of best practices (see Pulverer, 2010; see also Bedeian, 2003; Gosden 2003).

A glance at the review texts reveals to authors what they should consider when writing the text and how they can prepare. However, Tsang and Frey (2007) felicitously point out that "[a] simple fact about peer review is that not all referee comments help to strengthen a manuscript" (p. 129) (see also Haack, 2006). Sometimes, the blind review process is criticized for allowing the use of much harsher language than if the process was not anonymous as well as for making transparency of the process more difficult (e.g., Beyer, Chanove, \& Fox, 1995; Pulverer, 2010; Regehr \& Bordage, 2006).

From an author's point of view, a detailed, constructive feedback is the best, whether it was given anonymously or not. That makes revising the manuscript and responding to the referee's comments easy. How can reviewers provide such feedback? Often reading a piece is extremely laborious and completing reviews gets prolonged and, sometimes unfortunately, the reviewer does not have time to familiarize themselves with the text adequately. This was a concern pointed out, for example Glenn (1976) already quite a while ago in the American Sociologist, and the worry is the same today. Sloppily written reviews are not much help-neither do they fulfill the ethical criterion concerning timely reviews and constructive feedback (Benos et al., 2003).

Is caring peer review process possible? Kevin Kumashiro (2005, p. 258) has asked the same: "We are told that academia is not always a nice place and that to succeed in publishing we need to develop a 'tough skin' that buffers us against taking such criticism personally." Kumashiro (2005) suggests three ways to rethink the collaborative potential of the peer-review process: as constructive, as multilensed, and as situated. "Even with established researchers, giving suggestions for revisions can become part of a collaborative way to think about publishing - not as a process where we weed out the bad stuff, but one in which we support one another to produce the most useful research possible. And, as in the example above, the conversation can be collegial, even lighthearted, and not so depersonalized and inhumane." (Kumashiro, 2005, p. 260)

Therefore, the idea of caring peer review is not a new one; Kumashiro's thoughts about the possible 
collaborative nature of reviews actually shows the idea of seeing the peer-review process as an opportunity to develop research together-not by agreeing in everything but being frank with one's prejudices and open to new ways of considering research. Committing oneself with this kind of attitude might just open the curtain for caring about not only one's own deeply-rooted assumptions of publish-worthy research in the field but also about the open-minded development of science and, the most importantly, about the one who receives the review: Am I making suggestions and notes that truly help the author to revise and improve the paper? Am I treating the author fairly and tactfully? These two questions are, at least according to my experience in both sides of the process, the most crucial ones. Even good and constructive suggestions do not become understood as they should if the language used is rude; it just takes the attention away from the actual issues.

\section{The power of collaboration}

The second purpose of this article was to discuss the possibility of caring collaboration in writing. How to describe the power of working together when writing an article? First, we have to look at the concept of teamwork. For example, Seligman et al. (2005) defined teamwork as working well as member of a group or team, social intelligence as being aware of the motives and feelings of self and others, fairness as treating all people the same according to notions of fairness and justice, and kindness as doing favors and good deeds for others.

According to our studies on success at work (see Uusiautti, 2008; Uusiautti \& Määttä, 2013; 2015), the experience of success is a personal positive emotion, it may spring up after or while working together with co-workers, clients, or other people who are closely connected to the task at hand. When everyone in a team is excited and inspired in the task and developing, successful outcome may produce the most delightful experience of success (see also Losada \& Heaphy, 2004). The notion of the communal nature of the experience of success also highlights the fact that supportive and positive atmosphere at the work place may be an important contributor to the experiences of success, in other words, enhances the quality of work. Boreham (2004) uses the concept of collective competence to refer to making collective sense of events in the workplace, developing and using a collective knowledge base, and developing a sense of interdependency. Indeed, a common feature of the new ways of organizing work is their emphasis on teamwork.

It is important to notice that positive experiences at work can also be communal by nature. However, it requires some social character strengths (see Seligman et al., 2005). Lutgen-Sandvik, Riforgiate, and Vail Flecther (2011) found out that appreciation, challenge, success, opportunity, relationships, social support and team work, climate, supervisor/mentor, resources and triumphs are crucial for positive experiences at work (see also Deci \& Moller, 2005). Many of these features actually arouse from teamwork that also publishing work can be.

Uusiautti and Määttä (2013, pp. 19-20) outlined the connection of individual and communal factors with the perceived success at work with the dimensions of individual-communal and positive-negative resources at work. The study illustrated how a state were both negative individual and communal factors are present, is not likely to further the development of any positive emotions at work-neither at the individual nor at the communal level. Instead, it can be considered hindering the emergence of positive feelings and any emergence of collaboration. On the other hand, there is the possibility that the work community acts as a positive factor but the individual researcher may still have, for example, low self-esteem or suspicions against teamwork. Then there is a situation where the researcher community acts as negative factor but the individual researcher has a positive perception (Baumeister, 1993, see also Baumeister, Smart \& Boden, 1996) - this is a typical situation at work when individual employees enjoy their work fundamentally but the atmosphere at work is not very encouraging. The so-called ideal situation is where both the individual and communal factors are positive. This kind of starting point might be the core factor for the emergence of positively-toned teamwork and collaboration that can lead to various positive experiences such as flow (see Csikszentmihalyi, 2008) and joy of work (Varila \& Lehtosaari, 2001). Likewise, experiences of success both alone and together with the team become possible and more likely than in other abovementioned situations as it can, for its part, lead to maximal performances (see Avey, Luthans, 
Smith, \& Palmer, 2010; Kanfer \& Ackerman, 2005). Furthermore for example, intelligent thought and social inclusion has been proved to have a positive, direct relationship as well (Baumeister, Twenge, \& Nuss, 2002). Uusiautti and Määttä (2013) suggested that this kind of combination of positive individual and communal factors will also lead to well-being at work.

The support and encouragement from colleagues can be of irreplaceable value not only for a worker's own success and well-being at work, but also for the well-being and success of the whole work unit or work community. However, an academic community does not always represent such a positive work environment as described above. Competition, self-interest, and belittling of other's achievements lead to hostile academic work environment and suspiciousness between researchers (see e.g., Kramer, 1999). According to Kramer (1999), mutual trust has a number of important benefits for organizations and their members, and this applies to the academic communities as well. A good practical example of the open-minded collaboration is, therefore, writing and publishing together with colleagues about one's own or the team's joint research and related findings whereas mistrust between researcher colleagues and fear of someone stealing your ideas are quite common worries inhibiting collaboration (cf. e.g., Kramer, 1999; McAllister, 1995).

\section{Together in the riptide of publication process}

Currently, I work as a researcher in the field of educational sciences, and more often than not, research work is lonesome toil to many, including publishing attempts. The joy of collaborating in publishing is experienced by only a few researchers (Uusiautti, 2014). In general, the academic world could benefit from a more focused collaboration and peer support (e.g., Vaarala et al., 2013). However, writing together, each having a clear role in the publication could benefit many. The first and most important advantage is that when writing together, analyses and conclusions become profound in a way that one could not necessary reach alone, not to mention noticing various deficits in the paper that one might not even be aware of if doing the work along. Simply stated, sending a poor paper to review is waste of time, especially of the reviewers (Glenn, 1976).

Overall, having a trustworthy colleague read your text is beneficial in many ways. Discussions with the researcher-author team can open new possibilities to analyze the data that can lead to real innovations: new concepts, theories, and illustrations as well as new fields of research. One of my researcher friends wrote to me an email describing our fruitful collaboration:

"It sure is wonderful to work with this kind of team - perhaps we are making academic innovations with this terminology here." (Email from a researcher friend, 2014)

Another question is the manner of how reviewers provide their feedback. This question was discussed earlier in this paper. Of course, every reviewer is a human being and we are all different: what seems critical to one can be just another normal comment to another (Isen \& Reeve, 2006; Mäkikangas, 2007). We also accept feedback differently. As the peer review process goes on, the comments and critiques can be easier to digest and reply together. The usability and meaning of comments can be viewed with co-authors. Likewise, the phase of revising the text proceeds faster when the tasks are divided between co-authors and all do they share and spur each other. When writing alone, one can end up with ruminating the feedback for a long time and addressing it may start to appear overwhelming-which it is not in reality. The researcher team encourages and supports its members and helps to see the forest for the trees. All comments may not be that negative after all when they are studied separately and divided between co-authors in half or more depending on the size of the team. The result will energize and inspire, as the following email shows:

“This became a magnificent article. :-)” (Email from a researcher friend, 2014)

The most rewarding point is to hear the positive decision about publishing the manuscript and finally seeing the published piece. Everyone can read it now, information about the study is spreading, and one's fame as a researcher expands. The joy can be shared with co-authors: 
Uusiautti, S.

“I have great news!!! Congratulations to all of us!” (Email from a researcher friend, 2014)

Whether you wrote alone or with colleagues, familiarity with the publishing process will benefit you. The process can take long and requires hard work and various skills not only in a scientific sense but technically as well. It is always good to ask for help from colleagues and supervisors. Efficiency of review processes and smooth publishing processes (Bedeian, 1996; 2003; Neff \& Olden, 2006; Tsang \& Frey, 2007) are crucial, but caring scientific publishing also includes the mutual support and encouragement between researcher colleagues. Indeed, Ferres, Connell, and Travaglione (2004) point out, how at its best, working together, helping each other, and pursuing shared goals can provide the most enjoyable work experiences. The caring research approach draws from the positive. According to the study of Winter and Sarros (2002) in Australian universities, an academic work environment is motivating when roles are clear, job tasks are challenging, and supervisors exhibit a supportive leadership style. According to several studies (see e.g., Egan et al., 2009; Mayya \& Roff, 2004), good and supportive atmosphere makes research work seem meaningful and inspiring.

\section{Conclusion}

Today's work life requires new ways of enhancing collaboration between any employees, including ones working the academic organizations (Eisenberg, Goodall Jr., \& Trethewey, 2010). A human being is a social animal, says David Brooks (2011), and almost every employee, worker or academic, has to work within some kind of human network. We must see each other as a positive source and cherish reciprocity. Similarly, positive viewpoints can introduce new ways of perceiving academic work (cf. Uusiautti, 2013). For example, Pajares (see e.g., 2001) argues that positive psychological constructs can explain academic motivation and achievement. Likewise, Seligman (2011) emphasizes the role of positive social relationships even in achievements, such as the publication of an article. Most positive events in human life take place surrounded by other people.

It is a fact that the review process has a critical influence on researchers' careers as well as the development of scientific fields (see Beyer, Chanove, \& Fox, 1995). This is why the process also speaks to most of us. Kumashiro (2005, p. 263) sees an opportunity for collaborative review processes. He asks "What might it mean for a peer review to work conscientiously to help develop and create the field rather than merely reproduce the standards that others in the field have already defined for evaluating research?" The answer is to let go the old bad experiences, cynicism, and prejudices, and be honest with one's own lenses and be aware of how one situates one's reviews in relation to one's perspectives (Kumashiro, 2005). Only then it would be possible to analyze how ideas presented in the article could intertwine with earlier knowledge and research, and how to suggest the author to improve the paper. The outcome can represent a type of a collaborative theorizing that can be meaningful and instructive for both the author and the reviewer-this Kumashiro's idea is very close to the idea of caring peer reviews.

Actually, Kumashiro presents that reviewers should be willing to accept new ideas. Cooper (2009) takes the idea still a bit further by summarizing the qualities of a good reviewer. According to Cooper (2009), "a good deal of overlap" between the evaluative and collaborative roles of a reviewer:

(1) A good review is evaluative, but balanced.

(2) A good review evaluates the connection between a paper and the literature.

(3) A good review is specific and factually accurate.

(4) A good review is fair and unbiased.

(5) A good review is tactful.

(6) A good review treats the author as an equal. (pp. 85-87)

This might well form the core of caring peer review, but I would also like to add the element of timely 
action, sticking to the deadlines. That is caring too. To an author, to be in a situation when having waited for a review for weeks or months is frustrating, especially if the result is a superficial review. Caring review processes therefore include the ability to guarantee that the review is done in time.

But at the same time, we could ask a question: are these not the features of a caring collaboration in research in general? Academic work does not have to be like Seligman described it with a blink in his eye in Flourish (2011, p. 6): “[A]lmost all academic research I had known is funded through tedious grant requests, annoying peer reviews, officious bureaucracy, unconscionable delays, wrenching revisions, and then rejection and heart-stopping budget cuts". Instead, collaboration in academic publishing, as described in this article earlier, includes all the elements from tactfulness to fairness, trustworthiness to constructiveness. Nahata (2008, p. 1) summarizes: "Successful authors combine appropriate knowledge and experience, personal attributes, and effective collaborations to produce insightful and important contributions to the literature."

Ultimately, a process of publishing a peer-reviewed paper is quite a wide process, covering many parts of the academic world. Hojat et al. (2003) note that a publication of an article ties the editorial team with reviewers, contributors, readers and owners of the journal. Good, positive and caring practices reflect many agents in the field and can spread a good manner in publication work which is not only promoting well-being and positive experiences but also is likely to lead to more productive and efficient publication processes (cf. Achor, 2010). In practice, this kind of attitude toward research work is necessary: not only does it show caring about one's own career as a researcher and quality of one's work but also caring about the quality of science, quality of scientific publishing, and quality of collaboration in the academic world.

\section{References:}

Achor, S. (2010). The happiness advantage. The seven principles of positive psychology that fuel success and performance at work. New York, NY: Crown Business.

Avey, J. B., Luthans, F., Smith, R. M., \& Palmer, N. F. (2010). Impact of positive psychological capital on employee well-being over time. Journal of Occupational Health Psychology, 15, 17-28. http://dx.doi.org/10.1037/a0016998

Bakanic, V., McPhail, C., \& Simon, R. J. (1987). The manuscript review and decision-making process. American Sociological Review, 52, 631-642. http://dx.doi.org/10.2307/2095599

Baumeister, R. F. (1993). Self-esteem: the puzzle of low self-regard. New York, NY: Plenum. http://dx.doi.org/10.1007/978-1-4684-8956-9

Baumeister, R. F., Smart, L., \& Boden, J. M. (1996). Relation of threatened egotism to violence and aggression: the dark side of high self-esteem. Psychological Review, 103(1), 5-33. http://dx.doi.org/10.1037/0033-295X.103.1.5

Baumeister, R. F., Twenge, J. M., \& Nuss, C. K. (2002). Effects of social exclusion on cognitive processes: Anticipated aloneness reduces intelligent thought. Journal of Personality and Social Psychology, 83(4), 817-827. http://dx.doi.org/10.1037/0022-3514.83.4.817

Boreham, N. (2004). The theory of collective competence: Challenging the neo-liberal individualization of performance at work. British Journal of Educational Studies, 52(1), 5-17. http://dx.doi.org/10.1111/j.1467-8527.2004.00251.x

Bedeian, A. G. (1996). Improving the journal review process: the question of ghostwriting. American Psychologist, 51(11), 1189. http://dx.doi.org/10.1037/0003-066X.51.11.1189

Bedeian, A. G. (2003). The manuscript review process: the proper roles of authors, referees, and editors. Journal of Management Inquiry, 20(10), 1-8. http://dx.doi.org/10.1177/1056492603258974

Benos, D. J., Kirk, K. L., \& Hall, J. E. (2003). How to review a paper? Advances in Physiology Education, 27(2), 47-52. http://dx.doi.org/10.1152/advan.00057.2002

Beyer, J. M., Chanove, R. G., \& Fox, W. B. (1995). The review process and the fates of manuscripts submitted to AMJ. Academy of Management Journal, 38(5), 1219-1260. http://dx.doi.org/10.2307/256856

Black, N., van Rooyen, S., Godlee, F., Smith, R., \& Evans, S. (1998). What makes a good reviewer and a good 
review for a general medical journal? The Journal of the American Medical Association, 280(3), 231-233. http://dx.doi.org/10.1001/jama.280.3.231

Blank, R. M. (1991). The effects of double-blind versus single-blind reviewing: experimental evidence from The American Economic Review. The American Economic Review, 81(5), 1041-1067.

Bornman, L., \& Daniel, H.-D. (2009). The luck of the referee draw: the effect of exchanging reviews. Learned Publishing, 22, 117-125. http://dx.doi.org/10.1087/2009207

Brooks, D. (2011). The social animal. The hidden source of love, character, and achievement. New York, NY: Random House.

Campanario, J. M. (1996). Have referees rejected some of the most-cited articles of all times? Journal of the American Society for Information Science, 47(4), 302-310. http://dx.doi.org/10.1002/(SICI)1097-4571(199604)47:4<302::AID-ASI6>3.0.CO;2-0

Ching, G. S. (2013). Unraveling issues behind ISI misconceptions: An empirical study on the practical effects of academic publication. International Journal of Research Studies in Education, 2(3), 51-64. http://dx.doi.org/10.5861/ijrse.2012.288

Cooper, M. L. (2009). Problems, pitfalls, and promise in the peer-review process: Commentary on Trafimow \& Rice (2009). Perspectives on Psychological Science, 4(1), 84-90. http://dx.doi.org/10.1111/j.1745-6924.2009.01109.x

Deci, E. L., \& Moller, A. C. (2005). The concept of competence. A starting place for understanding intrinsic motivation and self-determined extrinsic motivation. In A. J. Elliot \& C. S. Dweck (Eds.), Handbook of competence and motivation (pp. 579-597). New York \& London: The Guilford Press.

Egan, R., Stockley, D., Brouwer, B., Tripp, D., \& Stechyson, N. (2009). Relationships between area of academic concentration, supervisory style, student needs and best practices. Studies in Higher Education, 34(3), 337-345. http://dx.doi.org/10.1080/03075070802597143

Eisenberg, E. M., Goodall Jr., H. L., \& Trethewey, A. (2010). Organizational communication. Balancing creativity and constraint. (6th ed.) Boston, MA: Bedford/St. Martin's.

Eisenhart, M. (2002). The paradox of peer review: admitting too much or allowing too little? Research in Science Education, 32, 241-255. http://dx.doi.org/10.1023/A:1016082229411

Ferres, N., Connell, J., \& Travaglione, A. (2004). Co-worker trust as a social catalyst for constructive employee attitudes. Journal of Managerial Psychology, 19(6), 608-622. http://dx.doi.org/10.1108/02683940410551516

Fortanet, I. (2008). Evaluative language in peer review referee reports. Journal of English for Academic Purposes, 7, 27-37. http://dx.doi.org/10.1016/j.jeap.2008.02.004

Glenn, N. D. (1976). The journal article review process: some proposals for change. The American Sociologist, 11(3), 179-185.

Gosden, H. (2001). "Thank you for your critical comments and helpful suggestions": compliance and conflict in authors' replies to referees' comments in peer reviews of scientific research papers. Ibérica, 3, 3-17.

Gosden, H. (2003). "Why not give us the full story?" Functions of referees' comments in peer reviews of scientific research papers. Journal of English for Academic Purposes, 2, 87-101. http://dx.doi.org/10.1016/S1475-1585(02)00037-1

Grimm, D. (2005). Suggesting or excluding reviewers can help get your paper published. Science, 309, 1974. http://dx.doi.org/10.1126/science.309.5743.1974

Haack, S. (2006). Peer review and publication: lessons for lawyers. Stetson Law Review, 789, 792-793.

Harnad, S. (1996). Implementing peer review on the net: Scientific quality control in scholarly electronic journals. In R. Peek, \& G. Newby (Eds.), Scholarly publication: The electronic frontier (pp. 103-108). Cambridge, MA: MIT Press.

Hojat, M., Gonnella, J. S., \& Caelleigh, A. (2003). Impartial judgment by the "gatekeepers" of science: Fallibility and accountability in the peer review process. Advances in Health Sciences Education, 8(1), 75-96. http://dx.doi.org/10.1023/A:1022670432373

Isen, A. M., \& Reeve, J. (2006). The influence of positive affect on intrinsic and extrinsic motivation: facilitating enjoyment of play, responsible work behavior, and self-control. Motivation and Emotion, 29, 297-325. 
Scientific publishing as the arena of power and caring

Kanfer, R., \& Ackerman, P. L. (2005). Work competence: a person-oriented perspective. In A. J. Elliot \& C. S. Dweck (Eds.), Handbook of competence and motivation (pp. 336-353). New York \& London: The Guilford Press.

Kramer, R. M. (1999). Trust and distrust in organizations: Emerging perspectives, enduring questions. Annual Review of Psychology, 50, 569-598. http://dx.doi.org/10.1146/annurev.psych.50.1.569

Kumashiro, K. (2005). Thinking collaboratively about the peer-review process for journal-article publication. Harvard Educational Review, 75(3), 257-285. http://dx.doi.org/10.17763/haer.75.3.h317564n18346928

Larochelle, M., \& Désautels, J. (2002). On peers, those 'particular friends'. Research in Science Education, 32 , 181-189. http://dx.doi.org/10.1023/A:1016026011664

Lock, S. (1982). Peer review weighed in the balance. British Medical Journal, 285, 1224-1226. http://dx.doi.org/10.1136/bmj.285.6350.1224

Losada, M., \& Heaphy, E. (2004). The role of positivity and connectivity in the performance of business teams: a nonlinear dynamics model. The American Behavioral Scientist, 47(6), 740-765. http://dx.doi.org/10.1177/0002764203260208

Lotriet, C. J. (2012). Reviewing the review process: Identifying sources of delay. Australasian Medical Journal, 5(1), 26-29. http://dx.doi.org/10.4066/AMJ.2012.1165

Lutgen-Sandvik, P., Riforgiate, S. E., \& Flecther, C. V. (2011). Work as a source of positive emotional experiences and the discourses informing positive assessment. Western Journal of Communication, 75(1). http://dx.doi.org/10.1080/10570314.2010.536963

Marsh, H. W., Jayasinghe, U. W., \& Bond, N. W. (2008). Improving the peer-review process for grant applications. Reliability, validity, bias, and generalizability. American Psychologist, 63(3), 160-168. http://dx.doi.org/10.1037/0003-066X.63.3.160

Mayya, S. S., \& Roff, S. (2004). Students' perceptions of educational environment. Education for Health, 17(3), 280-291. http://dx.doi.org/10.1080/13576280400002445

McAllister, D. J. (1995). Affect- and cognition-based trust as foundations for interpersonal cooperation in organizations. Academy of Management Journal, 38(1), 24-59. http://dx.doi.org/10.2307/256727

Mäkikangas, A. (2007). Personality, wellbeing and job resources. From negative paradigm towards positive psychology. Jyväskylä: University of Jyväskylä.

Nahata, M. C. (2008). Tips for writing and publishing an article. The Annals of Pharmacotherapy, 42, 1-5. http://dx.doi.org/10.1345/aph.1K616

Neff, B. D., \& Olden, J. D. (2006). Is peer review a game of chance? Professional Biologist, 56(4), 333-340. http://dx.doi.org/10.1641/0006-3568(2006)56[333:iprago]2.0.co;2

Pajares, F. (2001).Toward a positive psychology of academic motivation. The Journal of Educational Research, 95(1), 27-35. http://dx.doi.org/10.1080/00220670109598780

Pulverer, B. (2010). Transparency showcases strength of peer review. Nature, 468, 29-31. http://dx.doi.org/10.1038/468029a

Regehr, G., \& Bordage, G. (2006). To blind or not to blind? What authors and reviewers prefer. Medical Education, 40(9), 832-839. http://dx.doi.org/10.1111/j.1365-2929.2006.02539.x

Roth, W.-M. (2002). Editorial power/authorial suffering. Research in Science Education, 32, 215-240. http://dx.doi.org/10.1023/A:1016030212572

Seligman, M. E. P. (2011). Flourish. A visionary new understanding of happiness and well-being. New York, NY: Free Press.

Seligman, M. E. P., Steen, T. A., Park, N., \& Peterson, C. (2005). Positive psychology progress. Empirical validation of interventions. American Psychologist, 60(5), 410-421. http://dx.doi.org/10.1037/0003-066X.60.5.410

Tenopir, C., Mays, R., \& Wu, L. (2011). Journal article growth and reading patterns. New Review of Information Networking, 16(1), 4-22. http://dx.doi.org/10.1080/13614576.2011.566796

Tsang, E. W. K., \& Frey, B. S. (2007). The as-is journal review process: let authors own their ideas. Academy of Management Learning \& Education, 6(1), 128-136. http://dx.doi.org/10.5465/AMLE.2007.24401710

Uusiautti, S. (2008). “Today, I'll work better than ever” Success at work described by the employees of the year. 
[In Finnish]. (PhD Diss, University of Lapland, Rovaniemi, Finland).

Uusiautti, S. (2013). On the positive connection between success and happiness. International Journal of Research Studies in Psychology, 3(1), 1-11.

Uusiautti, S. (2014). Scientific publication as the scene of power and caring. In K. Määttä \& S. Uusiautti (Eds.), Strength from caring research. Educational Conference 6-7 Oct 2014 (pp. 45-54). Rovaniemi: University of Lapland. [In Finnish]

Uusiautti, S. (2015). The pressure of publishing. In S. Uusiautti \& K. Määttä (Eds.), Critical eye on education (pp. 79-96) Tallinn: United Press Global.

Uusiautti, S., \& Määttä, K. (2013). Does success at work produce well-being and happiness or vice versa? The International Journal of Interdisciplinary Organizational Studies, 7(3), 11-25.

Uusiautti, S., \& Määttä, K. (2015). The psychology of becoming a successful worker. Research on the changing nature of achievement at work. New York, NY: Routledge.

Vaarala, M., Uusiautti, S., \& Määttä, K. (2013). College students' experiences of and coping with loneliness possibilities of peer support. International Journal of Research Studies in Education, 2(4), 13-28. http://dx.doi.org/10.5861/ijrse.2013.510

Varila, J., \& Lehtosaari, K. (2001). Joy of work - earned by diligence, occurs by accidence or required by learning organization? [In Finnish]. Joensuu: University of Joensuu.

Wen, T. S., Ching, G. S., \& Tang, J. W. (2013). Realities in scholarly publication trends: A case study of a social science university in Taiwan. International Journal of Research Studies in Education, 2(2), 31-42. http://dx.doi.org/10.5861/ijrse.2012.146

Winter, R., \& Sarros, J. (2002). The academic work environment in Australian universities: A motivating place to work? Higher Education Research \& Development, 21(3), 241-258. http://dx.doi.org/10.1080/0729436022000020751 